\title{
Early discharge after acute myocardial infarction: risks and benefits
}

\author{
P Wilkinson, R Stevenson, K Ranjadayalan, B Marchant, R Roberts, A D Timmis
}

\begin{abstract}
Background-Thrombolytic treatment reduces mortality in patients with acute myocardial infarction but is associated with recurrent thrombotic events after admission, and it is unclear whether current practices of early hospital discharge are safe. Timing of first major adverse events (death, reinfarction, unstable angina, secondary ventricular fibrillation) in the early post-infarction period was studied to determine the risks.
\end{abstract}

Design-Follow up study.

Patients- 608 consecutive patients (447 men and 161 women) with confirmed myocardial infarction who were admitted to the coronary care unit of a district general hospital between January 1989 and December 1991. Clinical details, including the development of left ventricular failure and in hospital adverse events, were recorded prospectively. Follow up for out of hospital adverse events was carried out by review of the case notes, postal questionnaire, and where necessary, by telephone contact with the patient and his general practitioner.

Results-The risk (95\% confidence interval) of major adverse events in the first 10 days was $32 \cdot 3 \%(26.3$ to $39 \cdot 4 \%)$ in patients with heart failure and $7 \cdot 3 \%(5 \cdot 1$ to $9 \cdot 2 \%)$ in those without. Smoothed estimates of the event rate in patients without heart failure decreased from 5.9 events $/ 1000$ persons/day on day 6 to 3.4 events/1000 persons/day on day 10 and 0.9 events/ 1000 persons/day on day 21 . The corresponding cumulative risk estimates suggest that about 11 in every 1000 patients suffer a major, but often unpreventable, adverse event on day 6 or 7 after admission, and 23 in every 1000 do so between days 6 and 10.

Conclusions-The point at which the risk to the individual becomes acceptably low is a matter of judgement, but the risk of a major adverse event declines rapidly after a heart attack, and particularly for patients without heart failure discharge within a few days may be appropriate. Prolonging stay unnecessarily may use resources which could be more effectively used to treat cardiac disease in other ways.

(Br Heart f 1995;74:71-75)
Keywords: acute myocardial infarction; early discharge

Clinicians continue to debate the safety of discharging patients early from hospital after a heart attack. ${ }^{1}$ The desire to minimise the patient's hospital stay is in part driven by the wish to allow him to return home as soon as possible, and partly by the pressure to reduce the costs of health care. Against this have to be set the patient's safety and his need for rehabilitation. Over the past 25 years the lengths of hospital stay have fallen substantially, ${ }^{23}$ but there may be considerable variation between hospitals. ${ }^{45}$ The risk of death or other serious events is greatest in the first few days but rapidly decreases and studies from the late 1970 s and early 1980 s suggested that patients with an uncomplicated course may be discharged safely after a week, and some low risk patients even sooner. ${ }^{6-11}$ A recent study suggests the feasibility of using simple clinical variables to identify low risk patients (treated without thrombolysis) who may be suitable for discharge as early as 4 days after myocardial infarction. ${ }^{12}$

Thrombolytic treatment reduces hospital mortality, ${ }^{1314}$ but is associated with recurrent thrombotic events, and it is unclear how this affects the safety of early discharge. ${ }^{1516}$ The risks of major adverse events in general hospital patients has not been systematically quantified since the introduction of thrombolysis, yet lengths of stay continue to decrease. We have previously reported the follow up of a consecutive series of patients with confirmed myocardial infarction from a district general hospital in east London ${ }^{17}$ and we have used data from this study to examine the risk of major adverse events in the early postinfarction period.

\section{Patients and methods}

The methods are described in our previous report but are summarized here. ${ }^{17}$ The study population comprised 447 men and 161 women admitted to the coronary care unit of Newham General Hospital between January 1989 and December 1991. Twenty five patients were admitted twice, giving 633 separate admissions. During the study period it was policy to admit all patients with suspected myocardial infarction to the coronary care unit regardless of age.

Clinical details were recorded prospectively. The diagnosis of myocardial infarction 
required two of the following three criteria: typical chest pain; $>0 \cdot 1 \mathrm{mV}$ ST elevation in at least one standard lead or two precordial leads of the electrocardiogram, and a rise in serum creatine kinase to at least twice the normal laboratory value ( $>400 \mathrm{IU} / 1)$ ). The diagnosis of left ventricular failure indicates that the patient was breathless, had basal crepitations or a third heart sound, or both, and required treatment with diuretics. Primary ventricular fibrillation was ventricular fibrillation occurring in the first $24 \mathrm{~h}$. It was not classified as a major adverse event, but secondary ventricular fibrillation-that is, occurring after $24 \mathrm{~h}$, was considered to be a major adverse event.

Major adverse events (death, recurrent myocardial infarction, unstable angina, secondary ventricular fibrillation) during admission were recorded at the time; follow up for out of hospital events was carried out in June 1992 by review of the case notes and postal questionnaire to the patients. Non-responders were telephoned. Details of relevant events were checked with the general practitioner. Follow up was complete in 596 patients and censored at discharge in a further ten. Reliable information about major adverse events could not be obtained on two patients who were thus excluded from analysis.

During the study period, clinicians did not have a uniform policy on when to discharge patients after uncomplicated myocardial infarction. Their reported policies ranged from 7-12 days in 1988 to 5-8 days in 1991 . Overall the median length of stay was nine days, but the mode fell from nine days in 1988 to seven days in 1991 .

\section{STATISTICAL METHODS}

All analyses were based on the first admission for each patient during the study period. For the 25 patients admitted twice with myocardial infarction the second admission was recorded as a major adverse event.

Event free survival estimates were based on the Kaplan-Meier method. ${ }^{18}$ Multivariate predictors of adverse events in the first 10 days were obtained from logistic modelling, with improvements in model fit based on the likelihood ratio statistic.

The rate of major adverse events was calculated for each day after admission. The rate $\left(\lambda_{i}\right)$ for the $i^{\text {th }}$ day was $d_{i} / n_{i}$, where $d_{i}$ was the number of people who developed a major event on the $i^{\text {th }}$ day and $n_{i}$ the number still free of major events by the $i^{\text {th }}$ day. Smoothed rate estimates were obtained by Poisson regression, ${ }^{19}$ with the log rates modelled as a polynomial function of days since admission.

\section{Results}

Some 196 patients (32\%) developed clinical evidence of heart failure (left ventricular failure with or without cardiogenic shock). These patients were older than those without heart failure, a higher proportion were women, and more were diabetic or had a history of previous infarction; a smaller proportion had received thrombolysis (table 1 ). Seventy five patients eventually underwent revascularisation, but only 18 did so in the first 10 days: two $(1 \%)$ of those with heart failure and 16 (4\%) of those without.

Table 2 gives multivariate predictors of adverse events within 10 days. Heart failure was the most important, with an odds ratio of $3 \cdot 47$. The probability of developing a major event by 10 days was $32.3 \%$ ( $95 \%$ confidence interval (CI) 26.3 to $39.4 \%$ ) in patients with heart failure and $7 \cdot 3 \%(95 \%$ CI $5 \cdot 1$ to $9 \cdot 2 \%)$ in those without (fig 1). Older age, female sex, the presence of bundle branch block, and ventricular tachycardia were associated with increased risk, but primary ventricular fibrillation was not. Thrombolysis and aspirin use were associated with lower risk.

\begin{tabular}{|c|c|c|}
\hline & $\begin{array}{l}\text { Patients without } \\
\text { heart failure } \\
(n=412)\end{array}$ & $\begin{array}{l}\text { Patients with } \\
\text { heart failure } \\
(n=196)\end{array}$ \\
\hline $\begin{array}{l}\text { Age group (year) } \\
<50 \\
50-59 \\
60-69 \\
70+\end{array}$ & $\begin{array}{r}79(19) \\
133(32) \\
120(29) \\
80(19)\end{array}$ & $\begin{array}{l}16(8) \\
36(18) \\
65(33) \\
79(40)\end{array}$ \\
\hline$\underset{\mathbf{W}}{\operatorname{Sex}}$ & $\begin{array}{r}321(78) \\
91(22)\end{array}$ & $\begin{array}{r}126(64) \\
70(36)\end{array}$ \\
\hline $\begin{array}{l}\text { Race } \\
\text { White } \\
\text { Indian sub-continent } \\
\text { Other }\end{array}$ & $\begin{array}{l}312(76) \\
90(22) \\
10(2)\end{array}$ & $\begin{array}{r}156(80) \\
38(19) \\
2(1)\end{array}$ \\
\hline $\begin{array}{l}\text { Diabetes } \\
\text { Yes } \\
\text { No }\end{array}$ & $\begin{array}{r}55(13) \\
357(87)\end{array}$ & $\begin{array}{r}63(32) \\
133(68)\end{array}$ \\
\hline $\begin{array}{l}\text { Smoking } \\
\text { Never smoked } \\
\text { Ex-smoker } \\
\text { Current }\end{array}$ & $\begin{array}{r}95(23) \\
63(15) \\
254(62)\end{array}$ & $\begin{array}{l}65(33) \\
35(18) \\
96(49)\end{array}$ \\
\hline $\begin{array}{l}\text { Previous infarction: } \\
\text { Yes } \\
\text { No }\end{array}$ & $\begin{array}{r}81(20) \\
331(80)\end{array}$ & $\begin{array}{r}71(36) \\
125(64)\end{array}$ \\
\hline $\begin{array}{l}\text { Thrombolysis/aspirin treatme } \\
\text { Thrombolysis and aspirin } \\
\text { Thrombolysis only } \\
\text { Aspirin only } \\
\text { Neither }\end{array}$ & $\begin{array}{l}281(68) \\
37(9) \\
68(17) \\
26(6)\end{array}$ & $\begin{array}{l}106(54) \\
17(9) \\
35(18) \\
38(19)\end{array}$ \\
\hline $\begin{array}{l}\text { Probability of major } \\
\text { complication within } 10 \\
\text { days }(\%)\end{array}$ & $7 \cdot 3$ & $32 \cdot 3$ \\
\hline
\end{tabular}

Values in parentheses are percentages.

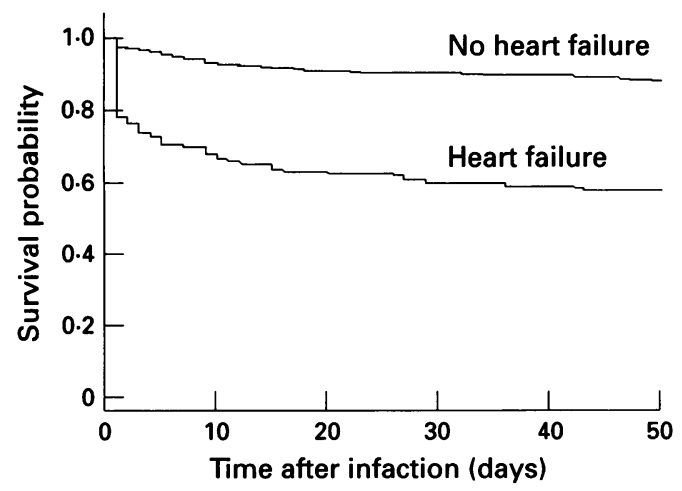

Figure 1 Event free survival by left ventricular function. 
Table 2 Multivariate predictors of a major adverse event within 10 days of infarction

\begin{tabular}{|c|c|c|c|c|c|}
\hline & $\begin{array}{l}\text { Odds } \\
\text { ratio }\end{array}$ & $\begin{array}{l}95 \% \\
\text { Confidence } \\
\text { interval }\end{array}$ & $\begin{array}{l}\text { Likelihood } \\
\text { ratio } \\
\text { statistic }\end{array}$ & $d F$ & $P$ Value \\
\hline $\begin{array}{l}\text { Heart failure } \\
\text { No } \\
\text { Yes }\end{array}$ & $\begin{array}{l}1 \\
3 \cdot 47\end{array}$ & 2.06 to 5.85 & $22 \cdot 3$ & 1 & $<0.001$ \\
\hline $\begin{array}{l}\text { Thrombolytic } \\
\text { No } \\
\text { Yes }\end{array}$ & $\begin{array}{l}1 \\
0.49\end{array}$ & 0.29 to 0.85 & $6 \cdot 30$ & 1 & 0.012 \\
\hline $\begin{array}{l}\text { Aspirin treatm } \\
\text { No } \\
\text { Yes }\end{array}$ & $\begin{array}{l}1 \\
0 \cdot 50\end{array}$ & 0.28 to 0.90 & $5 \cdot 16$ & 1 & 0.023 \\
\hline $\begin{array}{l}\text { Bundle branch } \\
\text { None } \\
\text { Right BBB } \\
\text { Left BBB }\end{array}$ & $\begin{array}{l}1 \\
2 \cdot 64 \\
4 \cdot 52\end{array}$ & $\begin{array}{l}1.25 \text { to } 5.58 \\
1.75 \text { to } 11.6\end{array}$ & $13 \cdot 7$ & 2 & 0.001 \\
\hline $\begin{array}{l}\text { Ventricular ta } \\
\text { No } \\
\text { Yes }\end{array}$ & $\begin{array}{l}1 \\
2 \cdot 42\end{array}$ & $1 \cdot 10$ to $5 \cdot 31$ & $4 \cdot 52$ & 1 & 0.034 \\
\hline $\begin{array}{l}\text { Age group (ye } \\
\quad \leqslant 60 \\
>60\end{array}$ & $\begin{array}{l}1 \\
2 \cdot 05\end{array}$ & 1.15 to 3.65 & $6 \cdot 11$ & 1 & 0.013 \\
\hline $\begin{array}{c}\text { Sex } \\
\stackrel{M}{F}\end{array}$ & $\begin{array}{l}1 \\
1 \cdot 69\end{array}$ & 0.99 to 2.89 & $3 \cdot 62$ & 1 & 0.057 \\
\hline
\end{tabular}

Figure 2 Rate of major adverse events after admission. (A) Solid points show 3 day means for patients with heart failure and the dashed line the corresponding regression fit (using data for individual days). Three day means (crosses) and the regression fit (solid line) for patients without heart failure are also shown in $(A)$ and again in (B) using expanded $x$ and $y$ axes.
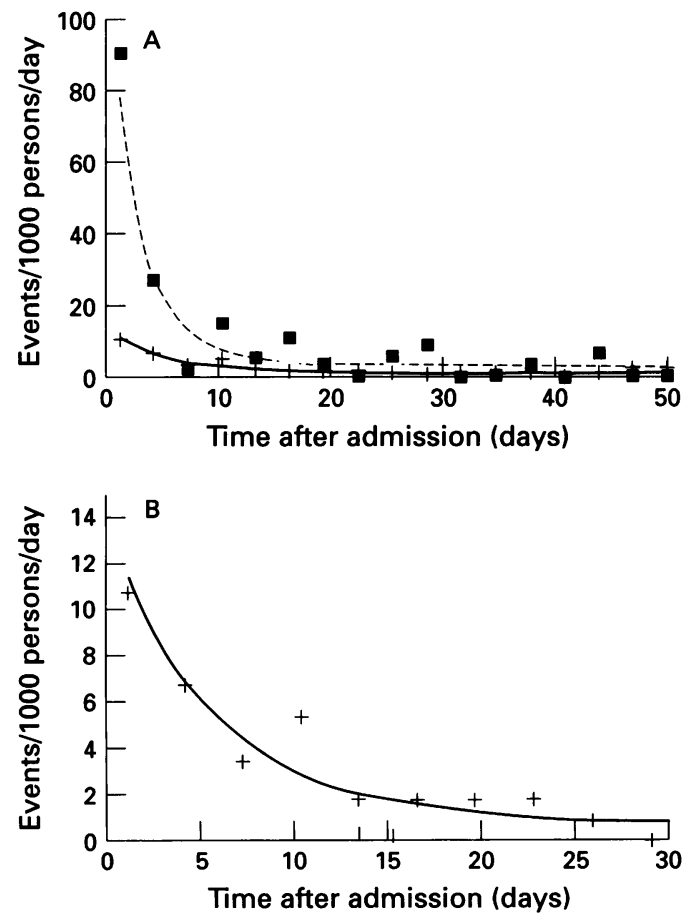

The cumulative risk in this group was $1 \cdot 1 \%$ between days 6 and 7 and $2 \cdot 3 \%$ between days 6 and 10.

A total of six adverse events were actually observed on days 6 and 7 in patients without heart failure, which represents an event rate for these two days of 7.65 (95\% CI 2.81 to $16 \cdot 7)$ events/1000 persons/day. This is slightly greater than the smoothed estimate from the regression fit. Over the five day period of days 6-10 13 patients without heart failure developed a major event; the corresponding rate was $6.72(95 \%$ CI 3.58 to 11.49$)$ events $/ 1000$ persons/day-again higher than the smoothed estimate.

Table 3 gives the characteristics of those without heart failure who developed a major adverse event between days 6 and 10. There were four in hospital deaths, five non-fatal reinfarctions, and three readmissions with unstable angina. The single episode of secondary ventricular fibrillation occurred immediately after coronary angiography. This table indicates that of 412 patients without heart failure, only five developed a major adverse event shortly after hospital discharge.

Review of the case notes suggested that of the 13 patients who developed a major adverse event between days 6 and 10, only five would probably have been fit for discharge after five days because of various medical problems. One of these died in hospital on day 6 , one developed unstable angina on day 10, and three had reinfarction (one on day 8 and two on day 10).

\section{COSTS AND BENEFITS}

It was not possible to quantify all costs and benefits of early discharge, but estimates were obtained of the potential saving on hospital care, and the expected additional number of adverse events which would occur outside hospital. The latter was computed from the smoothed estimates of risk, and the breakdown of different types of event-that is, death, reinfarction, secondary ventricular fibrillation, and unstable angina, was based on the proportions observed between 6 and 10 days. The calculations assume that all patients would be fit for discharge after five days and that the same complications would occur whether the patients were in hospital or at home.

For 1000 patients without heart failure discharge after five days rather than seven would increase the number of out of hospital events by about $10 \cdot 9: 3 \cdot 4$ deaths, $0 \cdot 8$ episodes of secondary ventricular fibrillation, 2.5 recurrent heart attacks, and 4.2 episodes of unstable angina. The cost of a bed on a general medical ward was estimated to be $£ 140$ per day, excluding specific investigation and treatment. Thus, for 1000 patients the approximate saving would be 2000 bed days at a nominal cost of $£ 280000$, although it may not be possible to redirect these resources to other uses.

Discharge after five days rather than 10 would save 5000 bed days at a cost of $£ 700000$ but be accompanied by the following out of 
Table 3 Characteristics of patients without heart failure who suffered a major adverse event between days 6 and 10 after admission

\begin{tabular}{|c|c|c|c|c|c|}
\hline $\begin{array}{l}\text { Event and day } \\
\text { on which it occurred }\end{array}$ & $\begin{array}{l}\text { Hospital } \\
\text { stay (days) }\end{array}$ & $\begin{array}{l}\text { Age } \\
\text { (years) }\end{array}$ & Sex & Thrombolysis & Comments \\
\hline $\begin{array}{l}\text { Death day } 6 \\
\text { Death day } 6 \\
\text { Ventricular fibrillation day } 6\end{array}$ & $\begin{array}{r}6 \\
6 \\
14\end{array}$ & $\begin{array}{l}74 \\
69 \\
67\end{array}$ & $\begin{array}{l}M \\
M \\
M\end{array}$ & $\begin{array}{l}\text { Yes } \\
\text { No } \\
\text { Yes }\end{array}$ & $\begin{array}{l}\text { Died in hospital } \\
\text { Patient had carcinoma of the stomach } \\
\text { Ventricular fibrillation occurred } \\
\text { immediately after angiography }\end{array}$ \\
\hline $\begin{array}{l}\text { Myocardial infarction day } 6 \\
\text { Death day } 7 \\
\text { Myocardial infarction day } 7 \\
\text { Unstable angina day } 8 \\
\text { Myocardial infarction day } 8\end{array}$ & $\begin{array}{r}15 \\
7 \\
6 \\
6 \\
21\end{array}$ & $\begin{array}{l}62 \\
75 \\
80 \\
58 \\
62\end{array}$ & $\begin{array}{l}\mathrm{M} \\
\mathrm{F} \\
\mathrm{M} \\
\mathrm{F} \\
\mathrm{F}\end{array}$ & $\begin{array}{l}\text { No } \\
\text { Yes } \\
\text { No } \\
\text { Yes } \\
\text { Yes }\end{array}$ & $\begin{array}{l}\text { Retroperitoneal bleed on day } 5 \\
\text { Died at night in hospital } \\
\text { Discharged day } 6 \\
\text { Diabetic. Discharged day } 6 \\
\text { Myocardial infarction in hospital. Well } \\
\text { on days } 5 \text { and } 7\end{array}$ \\
\hline Unstable angina day 10 & 7 & 58 & $\mathbf{F}$ & Yes & $\begin{array}{l}\text { Angioplasty on day } 2 \text {. Readmitted } \\
\text { with unstable angina }\end{array}$ \\
\hline $\begin{array}{l}\text { Unstable angina day } 10 \\
\text { Death day } 10\end{array}$ & $\begin{array}{r}5 \\
10\end{array}$ & $\begin{array}{l}58 \\
69\end{array}$ & $\begin{array}{l}\mathrm{F} \\
\mathrm{M}\end{array}$ & $\begin{array}{l}\text { Yes } \\
\text { No }\end{array}$ & $\begin{array}{l}\text { Discharged day } 5 \\
\text { Well on day } 6 . \text { Died on day of } \\
\text { discharge }\end{array}$ \\
\hline Myocardial infarction day 10 & 20 & 68 & $\mathbf{M}$ & No & $\begin{array}{l}\text { Equivocal chest pain on day } 5 \text {, so not } \\
\text { discharged }\end{array}$ \\
\hline Myocardial infarction day 10 & 9 & 77 & $\mathbf{M}$ & No & Readmitted with myocardial infarction \\
\hline
\end{tabular}

hospital complications: 6.9 deaths, 1.7 episodes of secondary ventricular fibrillation, 5.2 recurrent infarcts, and 8.7 episodes of unstable angina.

\section{Discussion}

This study examined a consecutive series of patients admitted to a district general hospital since thrombolytic treatment became routine in the management of myocardial infarction. As an observational study, it shows the outcome of patients who were subjected to a variety of different policies for investigation, mobilisation, and discharge, in the normal clinical setting. It does not answer the question of whether early discharge increases or decreases the frequency of complications, but it does provide a guide to the risk of death and other major adverse events in the early postinfarction period which should help clinicians formulate their own discharge policies.

Of the determinants of early outcome, heart failure was the most important and we used this factor to divide patients into high and low risk groups. The size of the study population does not allow the shape of the risk functions to be defined with precision and the smoothed estimates were slightly lower than observed values between six and 10 days. The rates should therefore be viewed as approximate indicators rather than precise estimates. Nevertheless, patients without heart failure clearly had a low absolute level of risk (less than $1 \%$ a day within three days of admission) which steadily declined. As there was no obvious point at which the decreasing risk reached a plateau, it becomes a matter of judgement to decide when the risk is acceptably low for safe discharge.

The risks have to be balanced against potential benefits. Delaying discharge ensures that more patients who develop adverse events receive immediate medical attention. Early discharge puts at risk a small additional number of patients and reduces the time available for in hospital rehabilitation and investigation (such as pre-discharge exercise electrocardiography), but may also have physical and psychological benefits. The resource implications may be substantial: the additional cost of hospital care amounts to around $£ 25000$ for each major complication on days 6 and 7 after admission, and many of these complications are not preventable. It is worth noting, for example, that in our study all deaths between six and 10 days occurred in hospital. Thus, early discharge could potentially save considerable resources which might be more effectively used to treat coronary disease in other ways.

The timing of discharge for patients with heart failure is often determined by clinical factors, but clinicians should be aware that for many patients without heart failure the risks of an adverse event are small and it seems reasonable to consider their discharge at five days or sometimes even earlier. Of course, each case must be decided individually on the basis of clinical assessment and any general policy flexibly applied. It may be appropriate to allow the early discharge of young, fit patients with good family support, but clinical judgement is always important and it is often social circumstances which dictate the timing of discharge rather than purely clinical considerations.

1 Goldstein S. Early discharge after a myocardial infarction: what's the hurry? F Am Coll Cardiol 1993;22:1802-3.

2 Hlatky MA, Cotugno HE, Mark DB, O'Connor C, Califf RM, Pryor DB. Trends in physician management of uncomplicated acute myocardial infarction, 1970 to 1987. Am ₹ Cardiol 1988;61:515-8.

3 McGovern PG, Folsom AR, Sprafka M, et al. Trends in survival of hospitalized myocardial infarction patients between 1970 and 1985: the Minnesota heart survey. Circulation 1992;85:172-9.

4 Lee TH, Gottlieb LK, Weitzman LJ, Mulley AG, Pauke SG, McNeil BJ. Lengths of stay of patients with uncomplicated acute myocardial infarction at three Boston hospitals: impact of pre-discharge tactics. F Gen Inter Med 1988;3:239-44.

5 Heller RF, Dobson AJ, Steele PL, et al. Length of hospital stay after acute myocardial infarction. Aust $\mathrm{NZ} \mathcal{F} \mathrm{Med}$ 1990;20:558-63.

6 McNeer JF, Wagner GS, Ginsburg PB, et al. Hospital discharge one week after acute myocardial infarction. charge one week after acute
N Engl $₹$ Med 1978;298:229-32.

7 Lau YK, Smith J, Morrison SL, Chamberlain DA. Policy for early discharge after acute myocardial infarction. for early discharge af

8 Severance HW Jr, Morris KG, Wagner GS. Criteria for early discharge after acute myocardial infarction: validation in a community hospital. Arch Intern Med 1982 142:39-41. 
9 Pryor DB, Hindman MC, Wagner GS, Califf RM, Rhoads MK, Rosati RA. Early discharge after acute myocardial infarction. Ann Intern Med 1983;99:528-38.

10 Madsen EB, Hougaard P, Gilpin E, Pedersen A. Lengths of hospitalization after acute myocardial infarction determined by risk calculation. Circulation 1983;68(1):9-16.

11 Herlitz J, Waldenstrom J, Halmarson A. Relationship between enzymatically estimated infarct size and clinical findings in acute myocardial infarction. Acta Med Scand 1984;215:21-32.

12 Sanz G, Betriu A, Oller G, et al. Feasibility of early discharge after acute $Q$ wave myocardial infarction in patients not receiving thrombolytic treatment. $₹ \mathrm{Am}$ Coll Cardiol 1993;22:1795-801.

13 ISIS-2 Collaborative Group. Randomized trial of intravenous streptokinase, oral aspirin, both or neither among 17,187 cases of suspected acute myocardial infarction: ISIS-2. Lancet 1988;ii:349-60.

14 AIMS Trial Study Group. Effect of intravenous APSAC on mortality after acute myocardial infarction: prelimi- nary report of a placebo-controlled clinical trial. Lancet 1988;i:545-9.

15 Gruppo Italiano per lo Studio della Strepochinasi nell'Infarcto Miocardio (GISSI). Long term effects of intravenous thrombolysis in acute myocardial infarction: final report of the GISSI study. Lancet 1987;ii: tion: $871-5$.

16 Simoons ML, Serruys PW, van de Brand $M$. Improved survival after early thrombolysis in acute myocardial infarction. Lancet 1985;ii:578-82.

17 Stevenson $R$, Ranjadayalan $K$, Wilkinson $P$, Roberts $R$, Timmis AD. Short and long term prognosis of acute myocardial infarction since introduction of thrombolysis. $B M \mathcal{F}$ 1993;307:349-53.

18 Kalbfleisch JD, Prentice RL. The statistical analysis of failure time data. London: Wiley, 1980:10-6.

19 Breslow NE, Day NE (eds). Statistical methods in cancer research. Vol II. The design and analysis of cohort studies. Lyon: International Agency for Cancer Research, 1987:131-42. 